\title{
Goran Stanivukovic, ed. Queer Shakespeare: Desire and Sexuality. London: Bloomsbury, 2017. Pp 424. Hardback: $£ 72.00$. ISBN: 9781350084476.
}

\section{EMER MCHUGH}

National University of Ireland, Galway

One of the most satisfying aspects of Goran Stanivukovic's edited collection Queer Shakespeare: Desire and Sexuality is the abundance of new and refreshing approaches to queerness in Shakespeare, and to the application of queer theory to Shakespeare's texts. In Stanivukovic's own words, Queer Shakespeare 'demonstrates that Shakespeare is an unavoidable presence in early modern England', and 'that he is constituent of queer theory just as queer theory without Shakespeare shuts itself away from one of its most resourceful presences' (26). In doing so, the book builds on recent pioneering work by scholars such as Madhavi Menon, Jeffrey Masten, and Mario DiGangi, as well as the previous work of the collection's own contributors. Stanivukovic wisely establishes the remit of the book, offering close examinations of the plays and poems through textual analysis and queer theoretical approaches and dividing the collection into three sections on 'queer time', 'queer language', and 'queer nature'. Given the prominence he accords to Emma Rice's 2016 production of A Midsummer Night's Dream at Shakespeare's Globe, as well as the emphasis Vin Nardizzi places upon that same production in his afterword, some exploration of the collection's themes through the means of performance studies would have been welcome too. But, as Stanivukovic appears to suggest, such analysis may better deserve its own specific volume, gesturing towards future work in queer Shakespeare studies.

The specific parameters and interests of Queer Shakespeare allow the collection to home in on recurring threads and themes that perhaps would be harder to draw together were it a broader volume. The collection is primarily concerned with style - that is, the formal qualities of Renaissance and early modern discourses of love and desire. Stanivukovic's assertion in his essay on queer styles in Twelfth Night that 'The materiality of language is inextricable from the materiality of the body that speaks it, and from the means by which that body is represented' arguably could act as a manifesto for the entire project (154). Many of the contributors, to no surprise, draw on Petrarchism throughout, whether to emphasize that literary style's contextual importance or, in the case of Ian Frederick Moulton's fascinating contribution, using Petrarch's sonnets as a gateway to draw the reader's attention to other comparative modes of literary and contextual analysis. Moulton introduces the reader to Antonio Beccadelli's Hermaphroditus (ca 1425), 
a collection of controversial Latin epigrams that are direct and explicit in terms of sex and desire (and unfortunately, pederasty). Such directness is apparent in some of the titles Beccadelli gives these epigrams (the English translation strongly reinforces this for a contemporary readership): one, for example, is titled Lepidinus Asks the Author Why Once Someone Begins To Butt Fuck He Never Stops. 'Beccadelli's and Shakespeare's collections of poems both centre on questions of queer desire', Moulton writes, 'and both can serve as crucial markers for the possibilities of articulating queer desire in early modern Europe' (99). Elsewhere, David L. Orvis explores the 'languages of love' - 'In thy opinion, which is worthiest love?' (1.2.6) - in The Two Gentlemen of Verona, and Valerie Billing expands upon the documentation of Love's Labour's Lost's 'lampooning of Petrarchism', suggesting that 'the play is also testing the limits of what kinds of desires Petrarchan tropes can articulate' (108-9).

To spotlight other contributions to Queer Shakespeare, Stephen Guy-Bray's illuminating chapter on the narrative excesses at play in Cymbeline offers a compelling reading of the complexities of how that play is structured. Cymbeline, as Guy-Bray demonstrates, is a heterosexual narrative told by queer methods; in its engagement with queer representations and its multiple resolutions, among others, 'the play is thus at once queer and not queer' (136). Meanwhile, Eliza Greenstadt elucidates the insidious nature of Antonio's possessiveness towards Bassanio in her persuasive reading of The Merchant of Venice. These essays are indicative of the broader challenging of received narratives that make the book such a valuable contribution. The exciting and surprising readings of texts and contexts which 'might seem like an obvious choice for a queer analysis' rejuvenate queer Shakespeare studies and show there is much still to uncover (123).

The collection also makes room for new and developing theoretical approaches in queer/Shakespeare studies. It is heartening to see trans studies included in this volume, as evidenced by Simone Chess's trenchant analysis of male femininity, 'transfemme', and cross-dressing in The Taming of the Shrew, A Midsummer Night's Dream, the Sonnets, and The Merry Wives of Windsor, among others: 'in taking men in women's dresses more seriously, we stand to deepen and complicate the variety of expressions of genders and gendered desire in Shakespeare's plays' (230). Chess thus shows that some of these characters are not just 'men in women's dresses'; in the case of Bartholomew the page in The Shrew, she argues that 'the trick on Sly is satirical, [as] the crossdressed lady need not be a joke' (242). John Garrison's contribution brings object studies into the equation; taking the use of 'glass' in Shakespeare's sonnets as his starting point, Garrison outlines a 
convincing analysis of glass's properties of reflection, distortion, and containment in approaching the Sonnets' queerness.

In its fresh appraisals of Shakespeare's plays and poems, Queer Shakespeare is a timely addition to the field of queer Shakespeares, and to that end, Shakespeare studies more broadly. As such, this collection will prove useful to scholars, educators, and students working in these areas. But Garrison and Nardizzi's comparative engagement with John Donne's poetry in their respective chapters, as well as Chess's passing reference to John Lyly's work, hopefully point towards further and more sustained engagement with queernesses in the work of other early modern writers and dramatists. The collection does not seek to have the last word on queer Shakespeare, nor on queerness in early modern literature, as the gestures towards future work in performance studies (for example) demonstrate. This collection is always looking towards queer futures in early modern literary and theatrical scholarship; a future which, on the basis of this collection, looks very promising. 
